\title{
Produksi Tepung Ikan Rucah Untuk Peningkatan Pendapatan Nelayan di Paciran Lamongan
}

\author{
Choirul Anam ${ }^{1}$, Cahyo Indarto ${ }^{2}$ \\ ${ }^{1}$ Agriculture of faculty. Darul ulum Islamic University \\ ${ }^{2}$ Agriculture of faculty. Trunojoyo University \\ Email: choirul.anam19@yahoo.com ${ }^{1}$, cahyo indarto@gmail.com²
}

\begin{abstract}
ABSTRAK
Tujuan dari pengabdian kepada masyarakat adalah untuk memberikan percontohan dan pelatihan kepada nelayan tentang teknologi produksi tepung ikan kaya protein berbahan baku ikan rucah yang berguna meningkatan pendapatan masyarakat nelayan. Metode yang digunakan adalah ceramah, diskusi ,demonstrasi atau pelatihan, pendampingan dan pemberian tugas serta analisa kelayakan usaha. Karakteristik anggota rukun nelayan sebagian besar umurnya antara 17 tahun sampai 47 tahun, berpendidikan Sekolah Menengah Pertama/MTs dan Sekolah Menengah Atas/MA. Pengalaman sebagai nelayan antara 5 sampai 20 tahun. Kebutuhan bahan baku ikan rucah sebanyak $10 \mathrm{~kg}$ dengan harga Rp 27.000 dan menghasilkan tepung sebesar $8 \mathrm{Kg}$ dengan harga jual $\mathrm{Rp} 7.000$ per Kg. Pendapatan kotor sebesar Rp 56.000,- dan keuntungan sebesar Rp 29.000. Perbandingan antara keuntungan dan biaya yang dikeluarkan, yaitu Rp. $29.000,00$ : Rp. $27.000,00=1,1(\mathrm{~B} / \mathrm{C})$. Jadi usaha tepung ikan cukup layak untuk dikembangkan dan dapat meningkatkan pendapatan nelayan sekitar 107 persen.
\end{abstract}

Kata kunci: nelayan, pendapatan, tepung ikan

\section{ABSTRACT}

The purpose of community service is to provide samples and training to fishermen about protein production technology of protein-rich fish protein from trash fish that is useful to increase fishermen's income. The methods used are lectures, discussions, demonstrations or training, mentoring and assignment and business feasibility analysis. Characteristics of members of harmonious fishermen most of the age between 17 years to 47 years, educated Junior High School / MTs and High School / MA. Experience as a fisherman between 5 to 20 years. Needs of raw materials trash fish as much as $10 \mathrm{~kg}$ with price $\mathrm{Rp} 27.000$ and produce flour of $8 \mathrm{Kg}$ with sale price $R p 7.000$ per $\mathrm{Kg}$. Gross income of $R p$ 56,000, - and profit of $R p$ 29,000. Comparison between profit and expenses, ie Rp. 29.000,00: Rp. 27.000,00 = 1,1 (B / C). So fish meal business is quite feasible to be developed and can increase fisherman income about 107 percent.

Keywords: fisherman, fish meal, income

\section{PENDAHULUAN}

Tepung ikan digunakan dalam formulasi pakan dengan tingkat pemakaian berkisar $15 \%$ pada pakan ikan/udang dan $5 \%$ pada pakan unggas. Apabila produksi pakan unggas mencapai 5 juta ton per tahun dan pakan ikan/udang sebesar 2 juta ton, maka sedikitnya dibutuhkan 0,25 - 0,75 juta ton tepung ikan setiap tahunnya. Dari kebutuhan tersebut, 70 $\%$ masih harus diimpor dari berbagai negara seperti Peru dan Chili. Pasar tepung ikan masih sangat terbuka 
luas, mengingat kebutuhan tepung ikan selalu meningkat dari tahun ke tahun. Impor tepung ikan Indonesia tahun 2000 menurut data BPS adalah 87.275 ton dengan nilai US\$ 39,483 juta, dan produksi pakan meningkat mencapai 5,75 juta ton. Ironisnya Indonesia sebagai negara bahari masih $70 \%$ mengimpor bahan baku. Harga tepung ikan impor sedikit lebih mahal dibandingkan produk lokal dengan kandungan protein dan kualitas yang sama. Harga tepung ikan lokal dengan protein $60 \%$ sebesar Rp $8.000 / \mathrm{kg}$ sedangkan produk impor berkisar $\mathrm{Rp}$ $9.500 / \mathrm{kg}$. Untuk tepung ikan impor harus dipesan 3 bulan di muka. Tepung ikan lokal kurang disukai karena kandungan protein yang rendah akibat dari penggunaan bahan baku maupaun proses yang tidak baik (Sutan, 2002).

Indonesia sampai saat ini baru mampu memproduksi tepung ikan lokal sebanyak 33.000 ton per tahun atau 9\% dari kebutuhan industri pakan ternak. Bahan baku lokal kebanyakan berasal dari ikan sisa. Teknologi produksi tepung ikan masih didominasi oleh skala kecil menengah menggunakan teknologi penepungan yang masih sederhana. Produksi tepung kini lebih diperuntukkan untuk konsumsi manusia. Diperkuat dengan dikeluarkannya SK Menteri Pertanian No 428 / Mentan / KI/1973 tertanggal 4 Oktober 1973 ditujukan kepada Gubernur di seluruh Indonesia. Isinya adalah "tidak membenarkan secara langsung penggunaan ikan konsumsi untuk bahan tepung ikan dan lokasi pabrik tepung ikan harus berdekatan dengan industri bahan sampingan". Kebanyakan industri tepung ikan berada di Jawa Timur (Muncar, Banyuwangi) dan Bali (Jembrana). Permasalahan utama tepung ikan lokal adalah karena rendahnya kandungan protein. Perusahaan pakan ternak sebagai pengguna bahan baku tepung ikan menghendaki kandungan protein minimal $60 \%$. Rendahnya kandungan protein pada tepung ikan local disebabkan oleh tidak sempurnanya proses produksi dan bahan baku yang tidak terpilih, yaitu ikan kering yang sudah rusak maupun sisa pengolahan ikan yang berupa kepala ikan dan tulang ikan sehingga proteinnya rendah. Demikian juga tepung ikan lokal lebih cepat rusak yang disebabkan oleh ketengikan akibat tingginya kandungan lemak pada tepung ikan, kondisi ini menurunkan kualitas tepung ikan.

Tujuan kegiatan ini adalah untuk meningkatkan partisipasi masyarakat dalam memanfaatkan ikan rucah menjadi tepung dapat terpenuhi, antara lain : a) mitra binaan dapat memproduksi tepung ikan dengan bahan baku ikan rucah; b) tersedianya tepung ikan kaya protein secara masal dan kontinyu pada mitra binaan; c) terjadinya peningkatan produktivitas olahan ikan rucah pada mitra binaan; d) peningkatan pendapatan bagi nelayan mitra binaan; e) Terciptanya lapangan kerja baru bagi nelayan dan keluarganya; f) 
harga tepung ikan bisa terjual Rp. $7000,-$ / kg

\section{METODE PENELITIAN}

Langkah-langkah untuk mencapai hasil yang diharapkan dari program ipteks bagi masyarakat dengan menggunakan metode pelaksanaan antara lain: ceramah; diskusi; demonstrasi atau pelatihan dan pemberian tugas. Sedangkan metode yang digunakan dalam melakukan pemberdayaan kelompok sasaran yaitu: pendekatan sosialisasi program pada tokoh masyarakat seperti ketua mitra rukun nelayan, ketua tempat pelelangan ikan di weru komplek setempat; dan pendampingan sampai kelompok sasaran bisa melakukan sendiri. Untuk langkah-langkah operasional yang diperlukan untuk mengatasi permasalahan yang dideskripsikan sebagai berikut: tahap observasi dan identifikasi permasalahan; tahap sosialisasi program kegiatan ipteks bagi masyarakat dengan melibatkan seluruh komponen masyarakat nelayan; tahap orientasi action lapangan, program pelatihan dan pendampingan. Pembuatan tepung ikan diuraikan berikut ini.

\section{Persiapan bahan.}

Sebagai bahan baku tepung ikan, dikenal dua macam ikan yaitu ikan yang mengandung lemak (ikan gemuk) dan ikan yang tidak mengandung lemak (ikan kurus). Pemilihan ini perlu diperhatikan karena berbeda dalam proses pembuatnnya. Ikan gemuk mengandung lemak yang banyak sehingga apabila digunakan sebagai bahan baku akan mengganggu, dengan menimbulkan bau. Bau yang timbul adalah akibat oksidasi yang terjadi pada lemak ikan tersebut saat penjemuran. Menurut Astawan dan Astawan (1989) oksidasi pada minyak disebkan oleh adanya oksigen dan dipacu oleh sinar matahari, sehinga bahan-bahan berminyak kalau dijemur mempunyai potensi untuk berbau tengik, karena pengaruh oksidsi tersebut.

Menurut Afrianto dan Liviawaty (1989), kandungan lemak pada ikan dipengaruhi oleh sifat-sifat biologisnya seperti ukuran, kedewasaan, musim dan jenis makanan. Ikan dalam keadaan kenyang mempunyai kandungan lemak yang tinggi. Kandungan lemak tertinggi dicapai pada saat ikan siap bertelur. Semakin tinggi kandungan lemak dari ikan, maka semakin rendah kandungan airnya. Variasi dan fluktuasi kandungan lemak antara lemak antar spesies sangat besar yaitu berkisar antara 0,3-30\%.

Pada persiapan bahan ini perlu dipisahkan bahan ikan dari kotorankotoran yang ada, hal ini penting dilakukan apabila bahan baku tepung ikan adalah sisa-sisa ikan yang umumnya diambil dari limbah samping proses pengolahan. Apabila bahan banyak mengandung air, maka perlu dilakukan penirisan lebih dahulu sebelum dilakukan proses selanjutnya. 


\section{Pencucian}

Bahan limbah ikan dicuci dalam bak pencucian. Caranya dengan memasukkan bahan ke dalam keranjang plastik yang berlubang di bawahnya. kemudian diletakkan dalarn bak pencucian dengan sistem air mengalir. Hal yang perlu diperhatikan dalam pencucian ini adalah kebersihan dari air pencuci. Air pencuci berperan dalam kaitannya kontaminasi mikrobia pada tepung ikan.

Proses pencucian ini bertujuan agar ikan yang akan diolah tidak tercampur dengan kotorankotoran seperti lendir, lumut yang melekat, lumpur dan lain-lain. Pencucian ini dilakukan dengan menggunakan air tawar. Jika tidak ada air tawar, maka dapat digunakan air laut yang bersih.

\section{Penggaraman}

Penggaraman ditujukan untuk melakukan pengendalian terhadap mikroorganisme. Banyak mikroorganisme yang tidak tahan tumbuh pada kondisi penambahan garam terutama mikroorganisme pembusuk, sehingga diharapkan dapat mengurangi kerusakan tepung ikan yang dihasilkan.

Penggaraman dilakukan dengan cara memasukkan bahanbahan ke dalam bak yang bersih. Penambahan garam sebanyak $5 \%$ dari berat bahan tepung ikan yang akan diolah. Penambahan garam dilakukan dengan pengadukan agar garam benar-benar bercampur dengan baik. Setelah bahan yang telah bersih

dimasukkan ke dalam bak penggaraman. Berikan garam, diaduk dan dibiarkan selama 30 menit.

\section{Pemanasan}

Pemanasan dapat dilakukan dengan perebusan ataupun dengan pengukusan. Tujuan dari pemanasan ini adalah untuk merusak jaringan dan pencairan lemak sehingga mudah dikeluarkan tahap-tahap ekstraksi lemak.

Lama pemanasan tergantung dari periode yang digunakan. Pengukusan dilakukan dengan menggunakan uap panas dan tekanan tinggi (2 atm) dengan suhu sekitar $115^{\circ} \mathrm{C}$ selama 1 jam atau tekanan 2 atm (sekitar $121^{\circ} \mathrm{C}$ ) selama 40 menit, dengan tujuan untuk mempermudah pada tahap ekstraksi lemak dan penggilingan.

Beberapa sumber menyebutkan bahwa untuk ikan dengan banyak lemak maka pemanasan ini sebaiknya dilakukan dengan penambahan air, atau direbus. Dengan direbus memudahkan ekstraksi lemak dari bahan ikan. Air panas diketahui dapat melarutkan lemak dengan baik.

\section{Pengepresan}

Masksud pengepresan ini adalah untuk mengurangi kadar air ikan dari $80 \%$ menjadi $35 \%$ sehingga memudahkan pengeluaran lemak dari ikan, memperhalus fraksi dan mempercepat proses pengeringan. Bila ikan masih mengandung lemak yang cukup tinggi, maka mutu tepung 
ikan akan rendah dan cepat mengalami ketengikan, sehingga daya simpan tepung ikan tidak lama. Faktor yang menentukan pengepresan adalah besarnya tekanan, lama pengepresan, ketebalan bahan yang dipres dan suhu pengepresan.

\section{Penggilingan dan Penambahan Antioksidan}

Ikan yang telah dipres (cake) kemudian digiling kasar (dihancurkan) dengan alat penggiling (penggilingan basah). Penggilingan dilakukan dengan penggiling berulir untuk skala besar maupun penumbukan. Tujuan dari penggilingan ini adalah untuk mempercepat pengeringan, karena dalam pengeringan semakin luas permukaan maka bahan yang dikeringkan akan semakin cepat kering. Pada tahap ini juga ditambahkan antioksidan yang merupakan campuran antioksidan BHA dan BHT, untuk mencegah terjadinya oksidasi pada tepung ikan selama proses pengeringan maupun penyimpanan.

\section{Pengeringan}

Pengeringan adalah suatu metode untuk mengeluarkan atau menghilangkan sebagian air dari suatu bahan dengan cara menguapkan air tersebut dengan menggunakan energi panas. Biasanya kandungan air bahan dikurangi sampai suatu batas agar mikroba tidak dapat tumbuh lagi di dalamnya (Winarno, 2002).
Salah satu cara pengolahan hasil perikanan adalah melalui proses pengeringan. Pada umumnya pengeringan ada dua macam yaitu pengeringan alami dengan memanfaatkan sinar matahari secara langsung (sun drying) dan pengeringan buatan (artificial) mechanical drying).

Di tingkat masyarakat nelayan, cara pengeringan yang dilakukan masih bersifat tradisional yaitu dengan menggunakan sinar matahari secara langsung dimana ikan diletakkan di atas para-para bambu secara terbuka. Cara penjemuran seperti ini kurang memenuhi syarat karena mudah dicemari oleh telur dan larva insekta serta mikroorganisme selama proses pengeringan berlangsung. Sehingga masyarakat nelayan menggunakan pestisida untuk membasminya. Penggunaan pestisida ini menyebabkan ikan tersebut tidak hygienis atau tercemar oleh bahan-bahan kimia yang dapat membahayakan kesehatan manusia (konsumen). Dengan demikan kualitas ikan tersebut sulit dijamin.

Selain itu juga pengeringan cara alami ini sangat tergantung pada cuaca atau kondisi lingkungan. Apabila cuaca baik maka proses pengeringan dapat berjalan dengan cepat. Sebaliknya apabila cuaca selalu mendung atau sering hujan, maka pengeringan memerlukan waktu yang cukup lama. Akan tetapi apabila ditinjau dari segi ekonomi, pengeringan alami ini lebih ekonomis karena peralatan yang digunakan 
sederhana dan murah dan tidak memerlukan keahlian khusus untuk pengoperasiaannya.

Sedangkan pada pengeringan buatan, faktor-faktor yang mempengaruhi proses pengeringan dapat diatur sesuai dengan kebutuhan dan tidak tergantung pada kondisi cuaca. Selain itu juga tingkat pengeringan produk yang dihasilkan lebih seragam, sehingga kualitas produk dapat ditingkatkan dan dijamin. Akan tetapi kerugian cara ini adalah memerlukan banyak energi sebagai sumber panasnya (Adawiyah, 2007).

\section{Penggilingan II}

Penggilingan ini bertujuan untuk mendapatkan tepung ikan dengan ukuran sesuai dengan yang dikehendaki. Tujuan penggilingan ini antara lain: Mempertinggi daya cerna dari produk yang bersangkutan; Memberikan daya campur yang lebih baik dengan bahan-bahan yang lain sehingga keseragaman lebih mudah dicapai; Memudahkan penyimpanan dan penanganannya, karena volumenya lebih kecil; Memperkecil resiko bahan-bahan yang terbuang seperti tulang, sisik, dan lain-lain.

\section{Pengemasan}

Pengemasan mempunyai tujuan utama yaitu untuk melindungi hasil olahan dari faktor-faktor luar yang tidak diinginkan seperti kotoran, kelembaban udara, dan lain-lain. Pada pembuatan tepung ikan umumnya pengemas yang digunakan adalah karung goni. Selama penyimpanan kadang terjadi perubahan warna dari tepung ikan yang mula-mula berwarna kehijauan menjadi kecoklatan. Hal ini karena terjadinya proses oksidasi lemak dalam tepung ikan (Buckle, et all. 1987).

\section{HASIL DAN PEMBAHASAN}

Karakteristik anggota (RN) rukun nelayan Weru komplek dilihat berdasarkan umur, pendidikan formal dan lama menjadi nelayan (pengalaman). Ada 15 orang yang mengikuti kegiatan ini. Kisaran umur anggota $\mathrm{RN}$ mitra $\mathrm{IbM}$ antara 17 sampai 47 tahun. Kisaran tersebut masih berada pada usia produktif. Sebagian besar anggota RN Weru komplek berpendidikan SD/MI, SMP/ MTs atau SMA/MA dan pengalaman dalam nelayan antara 5 sampai 20 tahun. Secara rinci karakteristik anggota RN Weru komplek dapat dilihat pada Tabel dibawah ini.

Tabel 1. Karakteristik Anggota RN Weru komple

\begin{tabular}{ccccc}
\hline No & Nama & Umur & Pendidikan & Lama \\
\hline 1 & Sodik & 30 thn & MA & 10 thn \\
\hline 2 & Muslik & 45 thn & MI & 15 thn \\
\hline 3 & Solikin & 17 thn & MTs & 2 thn \\
\hline 4 & Damu & 20 thn & MTs & 10 thn \\
\hline 5 & Wahyu & 33 thn & MA & 5 thn \\
\hline 6 & Kurnan & 35 thn & SMP & 5 thn \\
\hline 7 & Yusuf & 30 thn & MA & 5 thn \\
\hline 8 & Kusnadi & 34 thn & MTs & 5 thn \\
\hline 9 & Arifin & 33 thn & MTs & 10 thn \\
\hline 10 & Kholili & 47 thn & SMA & 15 thn \\
\hline 11 & Kusnan & 35 thn & SMP & 15 thn \\
\hline 12 & Munijar & 43 thn & MI & 20 thn \\
\hline 13 & Andi & 40 thn & MA & 5 thn \\
\hline 14 & Gandi & 40 thn & SMA & 10 thn \\
\hline 15 & Dorakim & 44 thn & MI & 20 thn \\
\hline
\end{tabular}




\section{Pembuatan Tepung Ikan.}

Kegiatan pelatihan dilakukan pada waktu para nelayan libur yaitu tiap hari jum'at pada bulan Juli sampai dengan Oktober 2013 di Kelompok Rukun Nelayan Weru komplek (Desa Paloh dan Sidokumpul), Kecamatan Paciran, Kabupaten Lamongan. Alat mesin penepung ikan berupa mesin pengepress hidrolis dan alat penepung ikan ditempatkan di kantor tempat pelelangan ikan (TPI) desa Paloh, sehingga jika masyarakat ke dua mitra yang ingin memproduksi tepung akan pergi ke TPI. Peserta kegiatan berasal dari anggota Rukun Nelayan Weru komplek tersebut sebanyak 15 orang (Tabel 1).

Materi penyuluhan dan pelatihan meliputi: penjelasan alat dan bahan baku (ikan) dan teknik memproduksi tepung ikan serta dilakukan tanya jawab mengenai materi tersebut terhadap masyarakat nelayan yang menunjukkan sangat responsib dengan kegiatan tersebut, karena merupakan pengalaman pertama bagi mereka untuk memproduksi tepung ikan dari hasil tangkapannya.

Kegiatan pendampingan mitra nelayan dilakukan dari bulan 18 Oktober sampai 18 November 2013. Masyarakat nelayan yang didampingi merupakan anggota mitra yang mengikuti kegiatan pelatihan. Pendampingan mitra nelayan dilakukan dengan pembuatan demonstrasi pembuatan tepung di daerah tempat pelelangan ikan (TPI) Desa Paloh, Paciran, Lamongan. Uji coba dilakukan pada tiga orang anggota kelompok yaitu
Saiful, Durakim dan Sodik. Dari hasil uji coba dapat diketahui bahwa sepuluh kilogram ikan rucah dengan harga $\mathrm{Rp}$. $2000,-/ \mathrm{Kg}$ dan minyak solar 1 liter dengan harga Rp. 6000,- serta bungkus plastik Rp. 1000,- , sehingga biaya yang dibutuhkan (10 x Rp. 2000,-) + Rp. $6000,-+$ Rp. 1000,- = Rp. 27.000,dapat menghasilkan tepung ikan sebanyak delapan kilogram dengan harga Rp. $7000,-/ K g$ atau (8 x Rp.7000,-) = Rp. 56.000,-. Pendapatan dari hasil tepung ikan Rp. 56.000,- - Rp. 27.000,- = Rp. 29.000,- atau 107 persen

Kegiatan pendampingan mitra nelayan dilakukan dari bulan 18 Oktober sampai 18 November 2013. Masyarakat nelayan yang didampingi merupakan anggota mitra yang mengikuti kegiatan pelatihan. Pendampingan mitra nelayan dilakukan dengan pembuatan demonstrasi pembuatan tepung di daerah tempat pelelangan ikan (TPI) Desa Paloh, Paciran, Lamongan.

Dari hasil uji coba lapang ini maka dapat disimpulkan bahwa masyarakat mitra dapat memproduksi tepung ikan dengan senang hati atau responsib dan menambah pendapatan sekitar 107 persen.

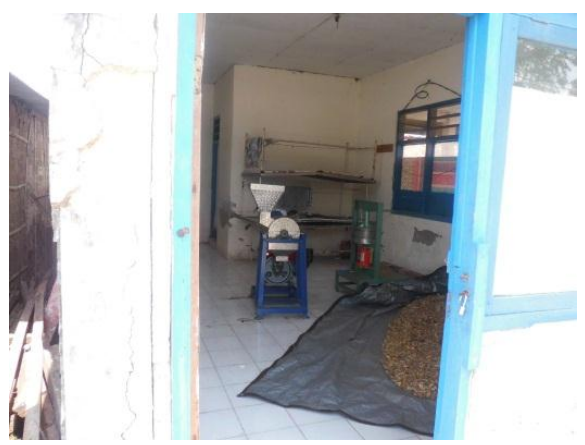

Gambar 1. Bahan dan alat Penepugan 


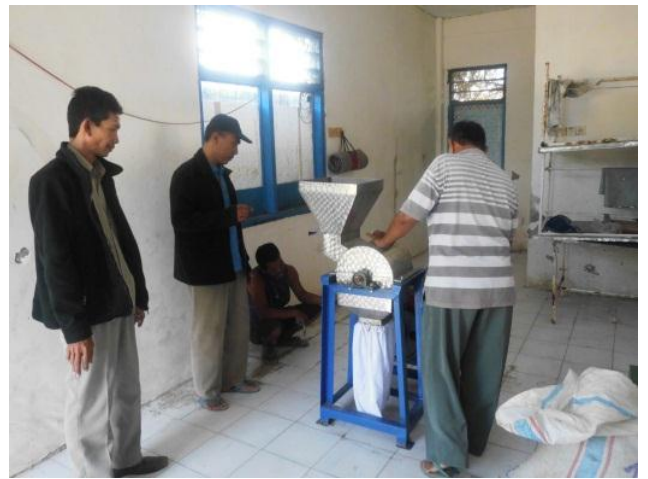

Gambar 2. Proses penepugan

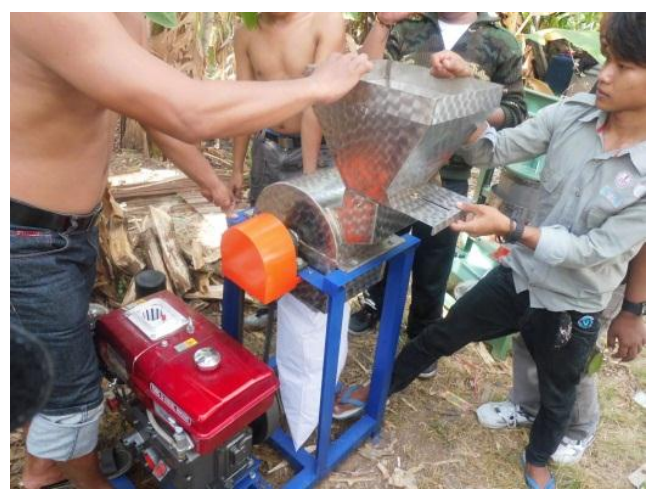

Gambar 3. Proses penepugan

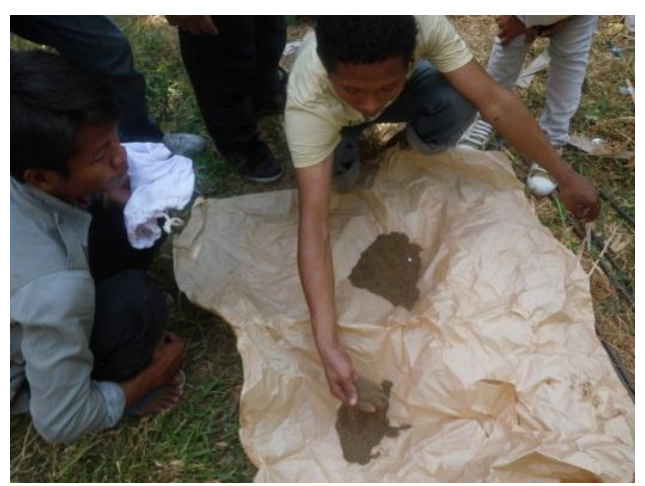

Gambar 4. Tepung ikan

\section{Analis Usaha Tepung Ikan}

Dalam program pengabdian kepada masyarakat nelayan di Weru komplek bahwa alat-lat penepung ikan dihibahkan dan diletakkan di tempat pelelangan ikan desa Paloh, Paciran, Lamongan. Dari hasil musyawarah diputuskan bahwa bagi nelayan yang menepung ikan akan dijadwal oleh ketua TPI secara bergantian. Sementara ini ada 4 orang nelayan yang tertarik untuk membuat tepung ikan, dengan analisa usaha sebagai berikut.

a. Biaya

$10 \mathrm{~kg}$ ikan rucah

@ Rp. 2000,- = Rp 20.000

1 liter m. solar

@ Rp. 6000,- = Rp 6.000

kantong plastik $=$ Rp. 1.000

Biaya Total $=$ Rp. 27.000

b. Penjualan dan keuntungan

Harga jual tepung ikan Rp. 7000,- per kg. Apabila proses pembuatan tepung ikan dapat berjalan optimal, maka dari $10 \mathrm{Kg}$ ikan rucah dapat dihasilkan $8 \mathrm{Kg}$ tepung ikan. Dengan demikian, besarnya hasil penjualan dan keuntungan dapat dihitung sebagai berikut.

Penjualan: $8 \mathrm{~kg}$ tepung ikan x Rp 7000 $=\operatorname{Rp} 56.000,-$

Keuntungan: Rp 56.000 - Rp 27.000 $=\operatorname{Rp} 29.000$,-

B/C Rasio: B/C rasio dapat dihitung berdasarkan perbandingan antara besarnya keuntungan dan biaya yang dikeluarkan, yaitu Rp. 29.000,00 : Rp. $27.000,00=1,1$

\section{SIMPULAN}

Kegiatan ini dapat disimpulkan bahwa Karakteristik anggota rukun nelayan di Weru komplek Kecamatan Paciran, Kabupaten Lamongan dilihat berdasarkan umur, pendidikan formal dan lama bekerja sebagai nelayan (pengalaman). Kisaran umur anggota RN Weru komplek antara 17 sampai 47 
tahun. Kisaran tersebut masih berada pada usia produktif. Sebagian besar anggota RN Weru komplek berpendidikan MTs/SMP atau MA/SMA dan pengalaman dalam mencari ikan atau nelayan antara 5 sampai 20 tahun. Hasil tangkapan ikan dijual pada pengepul.

Kegiatan pelatihan dilakukan pada hari Jumat mulai bulan Juli sampai dengan Oktober 2013 di Tempat Pelelangan Ikan Rukun Nelayan, Desa Paloh, Kecamatan Paciran, Kabupaten Lamongan. Peserta kegiatan berasal dari anggota Rukun Nelayan Weru komplek sebanyak 15 orang. Kegiatan pendampingan nelayan dilakukan dari bulan 18 Oktober sampai 18 November 2013. Nelayan yang didampingi merupakan anggota Rukun Nelayan yang mengikuti kegiatan pelatihan. Dari hasil uji lapang ini maka dapat disimpulkan bahwa pembuatan tepung ikan dapat meningkatkan pendapatan nelayan sekitar 107 persen.

Analisis keuntungan usaha dilakukan sebagai berikut : bahan baku ikan rucah sebanyak $10 \mathrm{~kg}$ membutuhkan biaya Rp 27.000 dan menghasilkan tepung $8 \mathrm{Kg}$ dengan harga jual $\mathrm{Rp} \mathrm{7.000/} \mathrm{Kg}$ atau $\mathrm{Rp}$ 56.000,-, sehingga keuntungan $\mathrm{Rp}$ 29.000. Perbandingan antara besarnya keuntungan dan biaya yang dikeluarkan, yaitu Rp. 29.000,00 : Rp. $27.000,00=1,1 \quad(\mathrm{~B} / \mathrm{C})$. Jadi usaha tepung ikan bagi nelayan Weru komplek, Paciran, Lamongan cukup layak untuk dikembangkan.

\section{UCAPAN TERIMAKASIH}

Penulis

mengucapkan

terimakasih kepada DRPM, Direktorat Jenderal Penguatan Riset dan Pengembangan Kemen Ristek Dikti atas dukungan finansial melalui DIPA NOMOR: DIPA023.04.1.673453/2013, tanggal 05 Desember 2012 Revisi ke 02 tanggal 1 Mei 2013

\section{DAFTAR PUSTAKA}

Adawyah, R. 2007. Pengolahan Dan Pengawetan Ikan. PT Bumi Aksara. Jakarta. 159 Halaman.

Afrianto, E dan E, Liviawaty 1989. Pengawetan dan Pengolahan Ikan. Kanisius. Yogyakarta. 125 Halaman.

Buckle, KA. RA, Edwards, G Fleet dan M Wootton. 1987. Ilmu Pangan. Universitas Indonesia Press. Jakarta.364 Halaman.

Esti, Sarwedi. 2001. Teknologi Tepat Guna Agroindustri Kecil Sumatera Barat. Dewan Ilmu Pengetahuan, Teknologi dan Industri Sumatera Barat.

Hadiwiyoto, S. 1993. Teknologi Pengolahan Hasil Perikanan Jilid 1. Liberty Yogyakarta. Yogyakarta. 275 Halaman.

Narbuko, C dan A, Achmadi. 2007. Metodologi Penelitian. Bumi Aksara. Jakarta. 206 Halaman.

Purnawijayanti, H. 2001. Sanitasi Higiene dan Keselamatan Kerja Dalam Pengolahan Makanan. 
Kanisius. Yogyakarta. 105

Halaman.

Susanto, T dan N. Sucipto. 1994.

Teknologi Pengemasan Bahan

Makanan. CV Famili Blitar.143

Halaman.

Winarno, S Fardiaz dan D.

Fardiaz.1980. Pengantar

Teknologi Pangan. Penerbit PT

Gramedia. Jakarta. 91 Halaman.

2002. Kimia Pangan Dan

Gizi. PT Gramedia Pustaka

Utama. Jakarta. 253 Halaman. 